\title{
The Religious Practices of Vietnamese Catholic Youth: The Case of the Diocese of Xuan Loc
}

\section{Le Minh Tien}

The Faculty of Sociology-Social Work-Southeast Asian Studies, Ho Chi Minh City Open University, Ho Chi Minh City, Vietnam Email: tien.lm@ou.edu.vn

How to cite this paper: Tien, L. M. (2017). The Religious Practices of Vietnamese Catholic Youth: The Case of the Diocese of Xuan Loc. Advances in Applied Sociology, 7, 271280 .

https://doi.org/10.4236/aasoci.2017.78017

Received: June 28, 2017

Accepted: July 24, 2017

Published: July 27, 2017

Copyright (C) 2017 by author and Scientific Research Publishing Inc. This work is licensed under the Creative Commons Attribution International License (CC BY 4.0).

http://creativecommons.org/licenses/by/4.0/ (c) (i) Open Access

\begin{abstract}
Every religion includes a whole series of beliefs and practices and we should start by concentrating our attention on religious practices to understand a religion. This paper intended to clarify the religious practices of Vietnamese Catholic Youth. Based on the theory of Glock and Stark and by using survey method, descriptive statistics, this is the first study to demonstrate the religious practices of youths in a diocese of Vietnam. This issue considered as an interesting research topic in the context of Vietnamese research because it explores youths lives from a different perspective by focusing on the micro level of analysis. The respondents in this study were total of 388 young adults between 18 and 30 years of ages from 24 parishes who were randomly selected through Probability Proportional to size sampling method. The findings of the research indicate that the ritualistic dimension of religiosity among Vietnamese Catholic youth is still so high in the context of change in Vietnam.
\end{abstract}

\section{Keywords}

Vietnam, Catholicism, Catholic Youth, Religious Practices, Xuan Loc

\section{Introduction}

As declared by Vietnamese communist government, the Socialist Republic of Vietnam is officially an atheist state, but in reality, the Vietnamese society is a multi-faith society. In point of fact, the Vietnamese people belonged to many forms of religious practice were animistic and totemic, and to the three great religions for a long time: Confucianism, Taoism and Buddhism. In comparison with these three religions, Roman Catholicism is a late religion that was introduced to this country in the $16^{\text {th }}$ century by the Portuguese Catholic missionaries. In 1960, Pope John XIII established the Vietnamese Hierarchy with Apostolic Constitution "Venerabilium Nostrorum". At this time, the Catholic Church 
in Vietnam was divided into three archdioceses: Ha Noi, Hue and Sai Gon. According to the 2009 Population and Housing Census of Vietnam (General Statistics Office of Vietnam, 2010), out of a population of more than 85 million people, 5.6 million people are Catholics (6.6\%) ranked second after Buddhists. By this reason, Vietnamese Catholics are the second biggest Catholic community in Southeast Asia after the Philippines.

Because of the importance of Catholicism in Vietnamese society, the life of this religion was an important research topic. In reality, most studies on Vietnamese Catholicism done to date focused on macro level of analysis such as that Pham (2008) studied the relationship between Confucianism and Catholicism in Vietnam in order to answer the question why under the great influence of Confucianism in Asia in general, Southeast Asia in particular, Catholicism still strongly develops in this country; Hansen (2009) sought to examine the Catholic Refugees from the North of Vietnam and their role in Southern Republic from 1954 to 1959 and he tried to answer why so many people left the North in 1954-1955 and why so many of them resettled separately from the "native" southern population; Trân (2010) examined the relationship between State and Church in Vietnam since the reform policy (Doi Moi) initiated in 1986; Keith (2012) provided the history of Catholicism in Vietnam from the mid-1800s through the end of French presence there in 1954. No study has yet been published on patterns of religious practice either within a particular religious community or within a total population in Vietnam. For this reason, this study could be considered as a micro level of analysis because our attention has been focused on the ritualistic dimension, one of the five dimensions of religiosity, of the young people of the Xuan Loc diocese. It is evident that the ritual practice expresses the life of a religion. This study, for the first time, contributed to the understanding of religious lives through empirical research and provided a starting point for conducting this type of study in the future.

\section{Overview of the Xuan Loc Diocese}

By a Bulla apostolica of Pope Paul VI, the Xuan Loc diocese was separated from the Sai Gon Archdiocese (now Ho Chi Minh City) and established on Oct 14, 1965. In a land area of 6439 square kilometers, the diocesan territory covers the whole Dong Nai province and Binh Duong province's Di An district. It is bounded on the north by the Phu Cuong diocese; on the east by dioceses of $\mathrm{Da}$ Lat and Phan Thiet; on the south by Ba Ria diocese and on the west by Ho Chi Minh City archdiocese. Bien Hoa city, the first class and capital of Dong Nai province, is an industrial center surrounded by many foreign and domestic factories and warehouses. According to the official statistics, in 2013, the diocese had 921.489 Catholics among a total population of more than 2 million, approximately including ethnic minority groups of Cho Ro, Khor, Ma, Stieng and Tay, served by one Bishop, 527 priests and 2.129 Religious. The diocese's Catholics distributed over 239.000 Catholic households among a total parish about 244. In terms of number, 
Xuan Loc has actually the highest percentage of Catholics among the local population of any diocese in Vietnam as seen in Table S1 in the Appendix.

\section{Objective of the Study}

This research tried to reveal one of five dimensions the religiosity of young people in a Vietnamese Catholic community through their involvement in religious practices because this issue could express the life of Catholism in the country and it is one of the ways to understand the religiosity of a religious community. Furthermore, a study on the religious practices of Vietnamese youth could have a potentially broad impact on the way parents, youth ministers, churches, and other organizations serve Vietnamese youth. We also sought to determine the factors that influenced on the religious practices of the young people concerned.

\section{Methodology}

Among the religions in the World, it is evident that the religious expressions are extremely varied: different religions expect different acts of their followers. Catholics are required to participate regularly in the sacrament of Holy Communion, Muslims are expected to take in charge a pilgrimage to Mecca during one's lifetime. Therefore, the diverse manifestations of religiosity proposed differently by different religions. The French sociologist Gabriel Le Bras states that practice is the exterior life of faithful and the only veritable adhesion to the church. This point is stressed in various discussions of culte, conduct and belief as the three essential parts of all religious life. Each possesses dimensions of visibility and hence can be observed in practice by the sociologist of religion (Shippey, 1965). According to Glock and Stark (1965), the religiosity could be calculated in five dimensions that cover all possible forms of religious expressions: The experiential dimension, the ideological dimension, the ritualistic dimension, the intellectual dimension and the consequential dimension.

The experiential dimension has to do with subjective religious experiences such as a feeling of God presence. The ideological dimension is constituted by expectations that the religious will hold to certain beliefs, every religion sets forth some set of beliefs to which its followers are expected to adhere. The ritualistic dimension includes the specific formalized religious actions that the followers of a religion are expected to perform. The intellectual dimension has to do with the expectation that religious person will be informed and knowledgeable about the basic tenets of his faith and sacred scriptures an the consequential dimension encompasses the secula effects of religious belief, practice, experience and knowledge on the individual life.

Because of the objectives above-mentioned and based on Glock and Stark's theory of religiosity, the survey research method was applied in this study. In reality, this study was in essence descriptive and the investigations carried out are quantitative. The study involves a sample of 388 young adults between 18 and 30 
years of age ${ }^{1}$ from 800 Catholic households. In order to have a representative sample of youth, the type of sampling method is Probability Proportional to size: the Primary Sampling Units are parishes, the Secondary Sampling Units are households and the Tertiary Sampling Units are individuals. Therefore, the sampling process was carried out in the three stages: at the first stage, 24 parishes were randomly recruited from a total 244 parishes; at the second stage, 800 households were randomly selected from 24 parishes; on the third stage, all young adults between 18 and 30 years of age of these households were selected. Of the 388 young people who participated in the study, 195 were female (50.3\%) and 193 were male (49.7\%). The survey was carried out directly and anonymously, using trained interviewers and questionnaire. Interviews were completed by the interviewer based on the respondent says. The survey was conducted on December 1 - 20, 2014 in the homes of the participants and in the most convenient place for the participants. Moreover, I utilized Statistical Package for the Social Science (SPSS) in analyzing the quantitative data being collected. The informed consent was established with the respondents and the confidentiality of the results was fully assured and was taken with consideration.

\section{Results and Discussion}

This shows the results of the survey conducted in December 2014 together with the presentation of the table based on the objective of the study. Table 1 presents the high ritual practices of young adults, especially in Mass attendance with more than 85 percent who attend Sunday mass or solemnities, just more than 1 percent said they didn't attend Mass for a long time. Why must Catholics go to Mass every Sunday? Because in the Third Commandment, the Lord told his people to "remember to keep holy the Sabbath day". In the Jewish tradition, the Sabbath was Saturday; for the Christians, however, this day was Sunday, the day of Jesus Christ's resurrection from the dead. For this reason, Catholics have an obligation to participate in the Sunday Mass, their chief form of worship as Christians. The result makes a difference between the Vietnamese Catholics and the Western Catholics because in many western countries, Sunday has become a day that is not so different from other days of the week.

In the confession, more than 95 percent said they confessed and only 4.7 percent said they didn't confess for a long time. Indeed, for the Catholism, the followers have to confess their sins at least once a year after having attained the age of discretion (Table 1).

Moreover, Catholics are required to profess publicly Catholicism, according to the teaching of Jesus "Therefore everyone who confesses Me before men, I will also confess him before My Father who is in Heaven. But whoever denies Me

${ }^{1}$ According to Vietnam's Youth Law in 2005 which took effect from $1^{\text {st }}$ July 2006, youth is defined as aged 16 - 30 years. But according to the Vietnam Civil Code, person under 18 years old is a minor, as such requires the legal representative agreement in civil transactions and according to the Vietnam Civil Procedure Code, people of at least 18 years old will have full capacity for civil conduct proceedings. For those reasons, youth is defined as aged 18-30 years in this study. 
Table 1. Religious practices among Vietnamese Catholic Youth.

\begin{tabular}{|c|c|c|}
\hline Participation in mass & Effective (n) & Percentage (\%) \\
\hline Sunday mass & 333 & 86.0 \\
\hline Some masses a week & 36 & 9.3 \\
\hline Attending daily & 10 & 2.6 \\
\hline Solemnities such as Christmas and Easter & 3 & 0.8 \\
\hline Do not attend for a long time & 5 & 1.3 \\
\hline Total & 387 & 100.0 \\
\hline \multicolumn{3}{|l|}{ Reciting prayers before sleeping at night } \\
\hline Every day & 225 & 58.3 \\
\hline A few days a week & 73 & 18.9 \\
\hline Rarely & 56 & 14.5 \\
\hline Almost never & 32 & 8.3 \\
\hline Total & 386 & 100.0 \\
\hline \multicolumn{3}{|l|}{ Confession } \\
\hline Regularly & 104 & 27.0 \\
\hline Special occasions such as Christmas and Easter & 263 & 68.3 \\
\hline Never for a long time & 18 & 4.7 \\
\hline Total & 385 & 100.0 \\
\hline \multicolumn{3}{|l|}{ Communion } \\
\hline Every mass attending & 312 & 81.9 \\
\hline Solemnities (Christmas. Easter) & 35 & 9.2 \\
\hline More than once a year (baptism or New Year ceremony) & 4 & 1.0 \\
\hline Never for a long time & 20 & 5.3 \\
\hline Others & 10 & 2.6 \\
\hline Total & 381 & 100.0 \\
\hline \multicolumn{3}{|l|}{ Bible reading } \\
\hline Everyday & 28 & 7.3 \\
\hline A few days a week & 81 & 21.0 \\
\hline A few times a year & 104 & 27.0 \\
\hline Almost never & 153 & 39.7 \\
\hline Others & 19 & 5.0 \\
\hline Total & 385 & 100.0 \\
\hline \multicolumn{3}{|l|}{ Occasions of private praying (multiple choice question) ${ }^{*}$} \\
\hline Attending mass & 250 & 66.5 \\
\hline Before sleeping at night & 213 & 56.6 \\
\hline Encountering difficulties & 166 & 44.1 \\
\hline Feeling of anxiety & 126 & 33.5 \\
\hline Thanksgiving & 21 & 5.6 \\
\hline Others & 38 & 10.1 \\
\hline
\end{tabular}

Note: ${ }^{\star} \mathrm{n}=376$. 
before men, I will also deny him before My Father who is in Heaven" (Matt. 10:32-33). Table 2 reports the results of four circumstances where Catholic young people could show their religious identity, particularly the circumstance related to Curriculum Vitae (CV). In fact, under communist regime, being Catholic is a disadvantage when applying for government agencies. The Catholics could be recruited, but they won't be leader in these agencies anywhere. So that, the self-determination as a Catholic in CV could be considered as a courage in the communist context (Table 2).

Overall, Vietnamese Catholic young adults sampled described a high level of religious practices. They were really devout in terms of ritual aspect.

Table 2. Self-determination as Catholic.

\begin{tabular}{|c|c|c|}
\hline In front of friends & Effective (n) & Percentage (\%) \\
\hline Always & 75 & 19.5 \\
\hline Frequently & 158 & 41.0 \\
\hline Sometimes & 90 & 23.4 \\
\hline Rarely & 40 & 10.4 \\
\hline Never & 22 & 7.7 \\
\hline Total & 385 & 100.0 \\
\hline \multicolumn{3}{|c|}{ At the office or at the school } \\
\hline Always & 83 & 21.4 \\
\hline Frequently & 154 & 39.8 \\
\hline Sometimes & 84 & 21.7 \\
\hline Rarely & 34 & 8.8 \\
\hline Never & 32 & 8.3 \\
\hline Total & 387 & 100.0 \\
\hline \multicolumn{3}{|l|}{ In Curriculum Vitae } \\
\hline Always & 138 & 35.6 \\
\hline Frequently & 159 & 41.0 \\
\hline Sometimes & 39 & 10.1 \\
\hline Rarely & 23 & 5.9 \\
\hline Never & 29 & 7.4 \\
\hline Total & 388 & 100.0 \\
\hline \multicolumn{3}{|c|}{ In social networking sites } \\
\hline Always & 46 & 12.1 \\
\hline Frequently & 66 & 17.4 \\
\hline Sometimes & 75 & 19.8 \\
\hline Rarely & 65 & 17.2 \\
\hline Never & 127 & 33.5 \\
\hline Total & 379 & 100.0 \\
\hline
\end{tabular}


Through the high level of religious practices among young people, we could conclude that the religious life of young adults in the Xuan Loc diocese is so strong. Firstly, it comes from the structure of the diocese. In reality, the majority of the Catholic population of Xuan Loc diocese were Catholic Refugees from the North of Vietnam after signing the Geneva Accords. The Geneva Accords were signed by the Democratic Republic of Vietnam (the North of Vietnam), France, the People's Republic of China, the Soviet Union and the United Kingdom on the morning of July 21, 1954 including the free movement of the population between the zone (the North of Vietnam and the South of Vietnam) for three hundred days. When this Agreement was really valid, many northern Catholics did leave the North. According to Hansen, the migrants who arrived in the South from the North included 676.348 Catholics $(76.3 \%$ percent of all northern refugees), whereas. The UN Refugee Agency (2000) accounted for an estimated 800.000 Catholics of those migrants, while the Republic of Vietnam (1956) estimated that there were 887.917 northern Catholics refugees in the South of Vietnam. The Catholics fled to preserve the faith because they did fear that their ability to practice their faith might be curtailed under the communist regime of the North. This fear was also reinforced by the perceptions of opportunity in the South, especially in the Sai Gon-Cho Lon area. Large parts of Bien Hoa and Dong Nai (now Xuan Loc diocese) were occupied by the northern Catholics who built their new communities based on the internal unity and cohesion principle. According to official statistics, in the Xuan Loc diocese, 57.0\% of parishes (139 parishes) were established in the period 1954-1975 with majority of northern catholics refugees ${ }^{2}$. So that, in the Xuan Loc diocese today, we can see many parishes that were under the name of original parish or community of the North such as Bui Chu, Phat Diem, Thai Binh, ect. For this reason, Catholics live under the pressure of the community and, as a result, they have to conform to the Church rules because of the taking part in a collective ritual creates a feeling of identification with the community of belonging and a feeling of same destiny.

Secondly, the high level of religious practices among Catholic Youth is based on the religious education program in the diocese. In reality, the catechist education program of Xuan Loc diocese is really strictest program. The catechist program called "Giao Ly Hong An" (Catechism of grace) divided into three levels: "Taking part in celebrating the Eucharist" for children aged 6 - 8. "Growing up in the Holy Spirit" for the $9-11$ age group and "Practicing Christian faith" for children aged 12 - 14. Only those Catholics who have competed this threelevel catechist program can be accepted for marriage preparation courses and receive the Sacrament of Matrimony. It is evident that this catechist program is different from other diocese: in the Ho Chi Minh Archidioces, for example, those who have completed the second level catechist (Growing up in the Holy Spirit) can be accepted for marriage preparation courses and receive the Sacrament of Matrimony. 
Table 3. Parents encourage to take part in religious practices (Percentage).

\begin{tabular}{ccccc}
\hline Frequency scale & Participation in mass & Confession & $\begin{array}{c}\text { Reciting prayers } \\
\text { before sleeping at night }\end{array}$ & $\begin{array}{c}\text { Catechist } \\
\text { learning }\end{array}$ \\
\hline Always & 32.2 & 20.6 & 24.5 & 21.8 \\
Frequently & 46.1 & 40.2 & 41.5 & 41.7 \\
Sometimes & 9.3 & 17.3 & 12.9 & 9.3 \\
Rarely & 6.7 & 15.2 & 12.4 & 9.3 \\
Never & 4.6 & 6.7 & 8.7 & 17.9 \\
Total & 100.0 & 100.0 & 100.0 & 100.0 \\
$(\mathrm{n})$ & $(388)$ & $(388)$ & $(388)$ & $(386)$ \\
\hline
\end{tabular}

On the other hand, Xuan Loc diocese has many organizations that Catholics must be member like: the Catholic Children organization, the Catholic Youth organization, the Catholic Mothers organization and the Catholic Fathers organization. Another contributing factor to the high religiosity of Vietnamese youths is the pressure of family. In reality, many Catholic young adults in the diocese of Xuan Loc live with their parents (78.9\% were living with their parents and $5.0 \%$ were living with their mom or dad), therefore, the family remains the important agency of religious socialization as seen in the Table 3.

Finally, the economic condition plays a significant role in the religious life of Vietnamese youths. In general, Vietnam is still a developing country with low personal security, recourse to religion becomes more important.

Overall, the process of religious socialization in the Xuan Loc diocese created the high level of religious practices among Catholic young adults in this diocese as the above results show.

\section{Conclusion and Recommendation}

The results of the study showed that religious practices in term of the ritualistic dimension among Vietnamese Catholic youth are still so high because of the strict organization and the religious education program of the Xuan Loc diocese. In the Xuan Loc diocese, the "parish civilization", the term particularly influenced by Yves Lambert (1985) still exists. The results confirm the consistency of the sharp difference between Vietnamese young adults and Western young adults on the religious practices (see Bibby, 2004; Meglio, 2012). This research study was limited to the ritualistic dimension of the religiosity. We think that the study of the frequency of religious practices is perhaps the simplest of the five dimensions of religiosity. The future research can improve this study through extending the dimensions of religiosity. Another limitation is that it focuses only on the statistics. The statistics may have significantly deep comments from qualitative interviews involved. Lastly, a comparative analysis between dioceses is an interesting research in understanding the religious practices of Vietnamese Catholic young adults today. 


\section{Acknowledgements}

The author would like to thank the Caritas of Xuan Loc diocese for the research grant that made this research possible. The author would also like to thank the anonymous reviewers for their comments.

\section{References}

Bibby, R. W. (2004). Restless Gods: The Renaissance of Religion in Canada. Toronto: Novalis/Saint Paul University.

General Statistics Office of Vietnam (2010). The 2009 Population and Housing Census of Vietnam. Ha Noi: Statistical Publishing House.

Glock, Y. C., \& Stark, R. (1965). Religion and Society in Tension. Chicago: Rand McNally \& Company.

Hansen, P. (2009). Bắc Di cu: Catholic refugees from the North of Vietnam, and Their Role in the Southern Republic, 1954-1959. Journal of Vietnamese Studies, 3, 173-221. https://doi.org/10.1525/vs.2009.4.3.173

Keith, C. (2012). Catholic Vietnam: A Church from Empire to Nation. Berkeley: University of California Press. https://doi.org/10.1525/california/9780520272477.001.0001

Lambert, Y. (1985). Dieu change en Bretagne: La religion à Limerzel de1900 à nos jours. Paris: Cerf.

Meglio, L. (2012). Religious Practice among Italian Youth: A Case Study in Lazio. Advances in Applied Sociology, 2, 89-94. http://dx.doi.org/10.4236/aasoci.2012.22012

Pham, H. T. (2008). Relationship between Confucianism and Catholicism in Vietnam. Religious Studies Review, 1, 40-50. http://www.vjol.info/index.php/RSREV/article/viewPDFInterstitial/4347/4124

Republic of Vietnam (1956). Cuoc di cu Lich su tai Viet Nam (A Historic Migration in Vietnam). Sai Gon: Presidential Commission for Refugees.

Shippey, F. A. (1965). The Relations of Theology and the Social Sciences According to Gabriel le Bras. Archives de Sciences Sociales des Religions, 1, 79-93.

http://www.persee.fr/doc/assr_0003-9659_1965_num_20_1_1788

https://doi.org/10.3406/assr.1965.1788

The UN Refugee Agency (2000). Les Réfugiés dans le Monde: Cinquants ans d Actions Humanitaires - La Fluite de IIndochine. Geneva: The UN Refugee Agency. http://www.unhcr.org/fr/publications/sowr/4b66d4fb9/refugies-monde-cinquante-ansdaction-humanitaire.html

Trân, T. L. (2010). Les Relations entre l'Église Catholique et l'État au Vietnam depuis le Đôi Mơi. Perspectives. Social Compass, 3, 345-356.

https://doi.org/10.1177/0037768610375519 


\section{Appendix}

Table S1. Distribution of Catholics in Vietnam*

\begin{tabular}{|c|c|c|c|}
\hline Dioceses & Catholics & Total Population & Statistic Year \\
\hline Ha Noi & 340,000 & $8,850,000$ & 2010 \\
\hline Bac Ninh & 124,200 & $8,000,000$ & 2010 \\
\hline Bui Chu & 384,453 & $1,825,771$ & 2010 \\
\hline Hai Phong & 134,846 & $5,150,000$ & 2010 \\
\hline Hung Hoa & 227,647 & $6,963,632$ & 2010 \\
\hline Lang Son-Cao Bang & 5,269 & $1,767,308$ & 2010 \\
\hline Phat Diem & 160,558 & 995,017 & 2010 \\
\hline Thai Binh & 135,178 & $3,250,000$ & 2010 \\
\hline Thanh Hoa & 138,839 & $3,800,000$ & 2010 \\
\hline Vinh & 497,806 & $5,383,000$ & 2010 \\
\hline Hue & 68,910 & $2,320,000$ & 2010 \\
\hline Ban Me Thuot & 397,211 & $2,730,956$ & 2010 \\
\hline Da Nang & 69,914 & $2,682,100$ & 2010 \\
\hline Kontum & 260,875 & $1,707,451$ & 2010 \\
\hline Nha Trang & 200,400 & $1,730,828$ & 2010 \\
\hline Qui Nhon & 69,512 & $3,785,600$ & 2010 \\
\hline Ho Chi Minh & 677,820 & $6,825,286$ & 2010 \\
\hline Ba Ria & 242,243 & $1,012,966$ & 2010 \\
\hline Can Tho & 196,932 & - & 2010 \\
\hline Đa Lat & 349,385 & $9,764,800$ & 2010 \\
\hline Long Xuyen & 217,526 & $5,353,857$ & 2010 \\
\hline My Tho & 120,300 & $4,776,036$ & 2010 \\
\hline Phan Thiet & 166,803 & $1,169,450$ & 2010 \\
\hline Phu Cuong & 131,345 & $2,888,328$ & 2010 \\
\hline Vinh Long & 196,155 & $3,976,522$ & 2010 \\
\hline Xuan Loc & 921,489 & $2,602,913$ & $2013^{* *}$ \\
\hline
\end{tabular}

Note: ${ }^{*}$ Catholic Bishops Conference of Vietnam. http://cbcvietnam.org/Church-in-Vietnam/Dioceses/; Note: **Diocese of Xuan Loc. http://giaophanxuanloc.net/gioi-thieu/lich-su-giao-phan-2.html. 
Submit or recommend next manuscript to SCIRP and we will provide best service for you:

Accepting pre-submission inquiries through Email, Facebook, LinkedIn, Twitter, etc. A wide selection of journals (inclusive of 9 subjects, more than 200 journals)

Providing 24-hour high-quality service

User-friendly online submission system

Fair and swift peer-review system

Efficient typesetting and proofreading procedure

Display of the result of downloads and visits, as well as the number of cited articles Maximum dissemination of your research work

Submit your manuscript at: http://papersubmission.scirp.org/

Or contact aasoci@scirp.org 